\title{
AS CRIANÇAS NO MOVIMENTO HIP HOP: PARTICIPAÇÃO DE MULHERES- REPRESENTATIVIDADE E (RE)EXISTÊNCIAS ${ }^{*}$
}

Mariana Semião de Lima

\section{Introdução}

Menina pretinha, exótica não é linda

Você não é bonitinha

Você é uma rainha.

Menina pretinha, exótica não é linda

Você não é bonitinha

Você é uma rainha.

Devolva minhas bonecas

Quero brincar com elas

Minhas bonecas pretas, o que fizeram com elas?

Vou me divertir enquanto sou pequena

Barbie é legal, mas eu prefiro a Makena africana

Como história de griôt, sou negra e tenho orgulho da minha cor Africana, como história de griô, sou negra e tenho orgulho da minha cor

Menina pretinha, exótica não é linda

Você não é bonitinha

Você é uma rainha.

O meu cabelo é chapado, sem precisar de chapinha

Canto rap por amor, essa é minha linha

Sou criança, sou negra

Também sou resistência

Racismo aqui não, se não gostou, paciência.

(Menina Pretinha - MC Soffia) 
Este é um dos meus raps favoritos. Escutei-o por diversas vezes. Com uma letra simples, mas forte, toda vez que o leio vêm à minha memória passagens da minha infância, em que as pessoas me chamavam de "exótica" ou "bonitinha". "Afinal das contas, meninas negras não podem ser simplesmente 'bonitas”. As meninas negras estão longe do referencial de padrão de beleza. Pelo seu tom de pele, por seu cabelo, por seus traços. Como todo rap deve ser, essa canção é uma (re)existência. Pela letra e também por ser de uma criança.

O presente capítulo tem como objetivo apresentar alguns resultados da minha dissertação de Mestrado, intitulada: Rap de batom: família, educação e gênero no universo rap, que discutiu a participação de mulheres no território masculino do gênero musical rap.

A partir da análise da trajetória de vida de três mulheres pioneiras do gênero musical rap em São Paulo, este estudo mostra que o processo de participação das mulheres em um movimento predominantemente masculino, apesar de difícil e competitivo, foi e é possível. Entre os anos de 2002 e 2003, esta pesquisa ${ }^{1}$ foi realizada em dois centros urbanos: Campinas e São Paulo. São Paulo, porque é o lugar histórico do movimento Hip Hop no Brasil, onde essa cultura se desenvolveu mais intensamente. Campinas, para comparar as diferenças e semelhanças entre uma metrópole e uma cidade interiorana.

\section{O movimento Hip Hop e a luta antissexista}

Expressão cultural da diáspora africana, o Hip Hop ${ }^{2}$ surgiu como experiência cultural juvenil associada às novas condições socioeconômicas em Nova Iorque, cidade antes industrial, e na década de 70, pós-industrial, condições que atingiram de forma mais direta aos jo-

\footnotetext{
${ }^{1}$ Optei pela pesquisa qualitativa de caráter etnográfico por considerá-la a opção metodológica mais adequada aos propósitos do estudo. Como estratégia de investigação, lancei mão de técnicas da pesquisa participante, que têm caráter dialógico, pois contemplam características e o contexto sócio-histórico dos sujeitos investigados sendo eles: a observação participante, entrevistas do tipo semiestruturadas e diário de campo (LUDKE; ANDRÉ, 1986).

${ }^{2} \mathrm{O}$ graffiti, o rap e o break são as expressões artísticas que formam a trilogia sagrada do movimento Hip Hop.
} 
vens afro-americanos e de origem hispânica, moradores do Bronx (ROSE, 1997). Esses jovens reelaboraram suas práticas culturais e começaram a produzir arte via as novas condições socioeconômicas surgidas.

No Brasil dos anos de 1970, eram os bailes blacks que contribuíram para o desenvolvimento do Hip Hop, principalmente em São Paulo. Nos bailes black, os clássicos do rap eram veiculados e concursos também eram realizados. Além desses espaços, a chegada do Hip Hop deve-se às revistas e aos discos importados, vendidos na Galeria 24 de Maio, no centro de São Paulo.

No final da década de 1990, uma avalanche de estudos urbanos (ANDRADE, 1996; CUNHA, 2003; DIÓGENES, 1998, FÉLIX, 2000; SILVA, 1998) passou a centrar-se na cultura Hip Hop. Esses estudos e pesquisas questionavam a razão de grupos juvenis se moverem na acepção de reivindicar melhorias e assim diminuir o caráter excludente de suas condições. Nessas pesquisas, o tema principal, a cultura juvenil, sua identidade, práticas e problemas característicos, abandonou a questão da presença feminina, como se o sinônimo de juventude fosse masculino, como se as mulheres fossem invisíveis. Nesse sentido, o trabalho de pesquisa de Magro (2003) foi pioneiro, ao investigar a experiência vivida por meninas grafiteiras no Hip Hop de Campinas.

Também nos anos 1990, o rap torna-se mais agressivo, mais "gângster". A agressividade masculina sempre foi um elemento importante nos raps, mas essa década foi tomada pelos "gangsta" ${ }^{3}$, rappers que cultuavam não só a bravata masculina mas a crueldade, bloqueando o resto. Esse novo discurso tornou-se assustador e preocupante, principalmente pela agressividade em relação às mulheres, que eram chamadas de putas ou vacas, não havendo nenhuma outra forma de se referir a elas. Até mesmo "gostosa” era uma expressão considerada leve demais para esses rappers ${ }^{4}$.

\footnotetext{
${ }^{3}$ Corruptela da palavra gangster, que na pronúncia black americana torna-se gangsta.

${ }^{4}$ Cf. Cavalcanti, B., Eisnberg, J., Starling, H. Rap: o canto à beira do precipício. Folha de São Paulo, 14 /10/2001. Caderno Mais, p. 4-9.
} 
No Brasil, muitas músicas produzidas por alguns rappers expressavam o discurso sexista por meio da exaltação do poder masculino. Era impossível falar das mulheres sem desrespeitá-las.

Mas na contracorrente desse discurso, muitas mulheres, que participaram desde o início desse universo predominantemente masculino, trouxeram a reflexão da desvalorização e do desrespeito do trabalho produzido pelas "minas" dentro do movimento e as desigualdades entre mulheres e homens, bem como os respectivos lugares dos gêneros na sociedade.

A forma de expressão e os assuntos abordados também se baseiam no mesmo cotidiano da periferia cantada pelos "manos", mas nas letras escritas por essas mulheres, seus próprios medos, anseios e experiências de vida são utilizados. São elas que ao comporem a respeito de temas como sexualidade feminina, tornam-se as "vozes antissexistas" do movimento, afirmando que não são objetos sexuais, mas sujeitas sexuais.

\section{Representatividade feminina e empoderamento}

Atualmente, dentro desse cenário, pode-se observar também a participação de crianças e jovens, dentre elas MC Soffia. A atuação da pequena $\mathrm{MC}$ Soffia ${ }^{5}$, que aos seis anos de idade descobriu seu desejo por cantar rap e começou a compor canções que abordam temas referentes a racismo, machismo e autoaceitação, não se deve a sua participação em oficinas de Hip Hop para crianças e jovens, ministradas em ONGs e escolas como atividades extracurriculares. Muito precocemente, a jovem rapper já frequentava, juntamente com seus familiares, os espaços nos quais a cultura negra se fazia presente na periferia da cidade de São Paulo.

MC Soffia, em um dos trechos da série criada pelo jornal $O E S$ tado de S.Paulo, no encarte Jornal da Cultura, traz a importância das mulheres pioneiras do Hip Hop para sua vida, e também mostra que

\footnotetext{
${ }^{5}<$ https://mdemulher.abril.com.br/cultura/mc-soffia-combatendo-0-racismo-commusica-desde-cedo/> Acesso: em 23 jan. 2020.
} 
ela já percebia os lugares estabelecidos para homens e mulheres nesse movimento de domínio masculino ${ }^{6}$.

Eu me inspirava ao ver as mulheres cantando. A música sempre foi muito masculina. Sempre existiram mulheres cantando, mas menos do que homens. E essas que cantavam não tinham tanta visibilidade. Então, a mulher podia cantar, mas ela não tinha a estrutura que um homem tinha. (MC Soffia)

Ou seja, para a jovem rapper, a visibilidade dada a outras mulheres cantando rap contribuiu no processo de construção de sua subjetividade. Ela se sentiu representada e isso foi muito importante para o fortalecimento de sua identidade e autoestima.

No trecho "O meu cabelo é chapado, sem precisar de chapinha”, apresentado na letra da canção rap no início deste capítulo, MC Soffia traz uma experiência vivida por muitas meninas negras: a necessidade de se encaixar no ideal estético feminino em nossa sociedade, o da mulher branca. Esse é um traço do paradigma epistêmico de produção de identidades dos colonizados. A rapper, que afirma já ter sofrido discriminação na escola por conta de seu cabelo crespo, se contrapõe a essa tentativa de branqueamento, afirmando não mais utilizar o alisamento.

A propagação de um discurso de empoderamento ${ }^{7}$ por meio das letras das canções de rap mostra mulheres e, nesse caso, infâncias, diversas nas vivências raciais, sociais, de gênero e classe. Também traz o protagonismo feminismo e a luta por direitos.

${ }^{6}<$ https://www.geledes.org.br/tv-cultura-exibe-deixe-ela-sonhar-com-mc-soffianesta-quinta-feira-05-12/> Acesso em: 10 jan. 2020.

${ }^{7}$ Baquero (2012) destaca a utilização da palavra em três categorias: individual, comunitária e organizacional. O termo empowerment ou empoderamento ganhou destaque com os movimentos emancipatórios, de negros, mulheres, homossexuais e pessoas com deficiência, a partir da luta por igualdade e justiça, durante a segunda metade do século XX, nos Estados Unidos. Dessa forma, surge o reconhecimento das habilidades e capacidades dos indivíduos, como seres autônomos, protagonistas das suas próprias histórias. 
Mulheres e meninas reagem à colonialidade, reprodutora do colonialismo, que se mantém viva na modernidade cotidiana a partir de muitos aspectos da vida: no comportamento, na cultura, no currículo escolar, nos materiais didáticos, etc. Apesar de o colonialismo tradicional ter chegado ao fim, a colonização epistemológica continua fortemente presente nos dias atuais.

A modernidade, invenção das classes dominantes europeias, a partir da conquista da América Latina, está intrinsecamente ligada à experiência colonial.

A Europa moderna, desde 1492, usará a conquista da América Latina (já que a América do Norte só entra no jogo no século XVII) como trampolim para tirar uma "vantagem comparativa" determinante com relação a suas antigas culturas antagônicas (turco-mulçumana, etc.). Sua superioridade será, em grande medida, fruto da acumulação de riqueza, conhecimentos, experiências, etc., que acumulará desde a conquista da América Latina. (DUSSEL, 2005, p. 30)

Foi com a modernidade que a Europa pôde produzir um modelo único e universal na produção de conhecimento. Para isso, foi necessário, segundo Dussel (2005), que a civilização europeia se autodescrevesse como a mais desenvolvida e superior, utilizasse um processo civilizador exercido através da violência, se necessário, que justificou a guerra colonial. Em outros termos, as classes dominantes europeias inventaram que sua razão era universal, negando o mundo periférico colonial.

O pós-colonial, segundo Ballestrin (2013 apud Arroyo 2018, p. 28), "se caracteriza como um movimento epistémico, intelectual, político que oferece análises críticas da historiografia colonial eurocêntrica”.

Segundo Arroyo (2018, p. 29):

Os estudos pós-coloniais convidam a buscar novas formas de pensar, novas epistemologias e novas práticas políticas e peda- 
gógicas e a rever espistemologias persistentes universalistas, subalternizadoras de ver os Outros e ver as Outras infâncias. Os estudos pós-coloniais nos alertam que não existe uma produção única de uma infância única, universal. Nem existe uma concepção epistemológica única, universal de ser humano.

MC Soffia, em uma entrevista ${ }^{8}$ ao canal Nova Escola, fala da importância de a escola descolonizar seu pensamento e trazer informações para as crianças que não inferiorizem grupos sociais, étnicos, raciais e suas infâncias.

Apesar de toda a consciência política vista na jovem rapper, Carneiro (2019) demonstra certa preocupação com relação aos desafios que as futuras gerações de mulheres terão que enfrentar:

As mulheres de minha geração compreenderam o sentido das palavras liberdade e igualdade em função da sede que a ausência de liberdade e de igualdade nos provocou. E essa sede era tão intensa que transformou as noções de liberdade e igualdade nos princípios mais caros as pessoas de nossa geração, porque além de entender que liberdade e igualdade são valores intrínsecos e inegociáveis para a pessoa humana, descobrimos também que para conquista-las e mantê-las é preciso muita disposição de luta e uma vigilância permanente para defendê-las, porque liberdade e igualdade são bens que estão sempre sendo colocados em perigo por diferentes ideologias autoritárias, fascismos, neofascismos, por diferentes variações do machismo, pelo racismo e as discriminações étnicas e raciais, pelos fundamentalismos religiosos, pelos neoliberalismos, pelas globalizações (CARNEIRO, 2019, p. 109).

Ou seja, tais ideologias colocam em risco conquistas, lutas e sonhos de muitas mulheres, e cabe às novas gerações continuarem travando um bom combate para as causas mais justas da humanidade.

\footnotetext{
${ }^{8} \mathrm{Na}$ escola com MC Soffia $<$ https://www.youtube.com/watch?v=Spoph3Y JKk. $>$ Acesso em: 7 fev. 2020.
} 


\section{Considerações Finais}

Em minha pesquisa de Mestrado, ao problematizar as relações vividas pelas mulheres no contexto do movimento Hip Hop, mais especificamente, as mulheres do gênero musical rap, a intencionalidade foi, além de apresentar um movimento de cunho cultural que se estabeleceu como um instrumento de afirmação, resistência e re-existência dos jovens negros e periféricos, abordar a condição da mulher em um espaço predominantemente masculino. No início dos anos 1990, quando esse estilo musical ganhou espaço na indústria fonográfica brasileira, a participação das mulheres era rara, mas aos poucos essa situação foi mudando. A presença feminina foi ganhando o seu espaço timidamente, por conta do sexismo. Hoje, além das mulheres terem seu lugar garantido, existe a inserção de outros grupos subalternizados, como as crianças e as pessoas LGBT.

A luta dessas mulheres por igualdade, reconhecimento e respeito, principais reivindicações das vozes femininas, não só do Hip Hop, mas de outros grupos e coletivos sociais femininos de origem popular, demonstra o protagonismo de mulheres em diferentes espaços ao longo da história. Nesse sentido, o presente texto, ao refletir acerca da participação de mulheres e crianças, inspira a pensar o movimento estigmatizado do Hip Hop como possibilidade de projeto político disposto a combater a discriminação, o machismo e a subalternidade de sujeitos invisibilizados.

Para finalizar, a autoarfimação, a autovalorização, o autorreconhecimento e autoconhecimento (BERTH, 2019), proporcionados pela participação de mulheres no Movimento Hip Hop, criaram estratégias para que crianças e jovens, como a rapper MC Soffia, percebam sua realidade, aceitem suas características culturais e estéticas e promovam ações para o coletivo. 


\section{Referências}

ADICHIE, Chimamanda Ngozi. Para educar crianças feministas: um manifesto. 1. ed. São Paulo: Companhia das Letras, 2017.

ANDRADE, Elaine Nunes. Movimento negro juvenil: um estudo de caso sobre jovens rappers de São Bernardo do Campo. São Paulo, 1996. (Dissertação de mestrado) Faculdade de Educação, USP, São Paulo, 1996.

ARROYO, Miguel. Descolonizar o paradigma colonizador da infância. In: SANTOS, Solange E; SANTIAGO, Flávio; BARREIRO, Alex; MACEDO, Elina E.; FARIA, Ana Lúcia G. Pedagogias descolonizadoras e infâncias: por uma educação emancipatória desde o nascimento Maceió: Edufal, 2018. p. 57-68.

BAQUERO, Rute Vivian Angelo. Empoderamento: instrumento de emancipação social? - Uma discussão conceitual. In: Revista Debates. Porto Alegre: v. 6, n. 1, p. 173-187, jan.-abr. 2012.

BERTH, Joice. O que é empoderamento? São Paulo: Editora Letramento, 2018.

CARNEIRO, Sueli. Escritos de uma vida. São Paulo: Pólen Livros, 2019.

CAVALCANTE, B.; EISNBERG, J.; STARLING, H.. Rap: o canto à beira do precipício. Caderno Mais. Folha de São Paulo, 14 /10/2001.

CUNHA, Maria Amália. Trajetos sinuosos: o bairro, a família e a juventude a sum só tempo. Campinas, 2003. (Tese de doutorado): Faculdade de Educação, UNICAMP, Campinas, 2003.

DIÓGENES, Glória. Cartografias da cultura e da violência: gangues, galeras e o movimento Hip Hop. São Paulo: Annablume; Fortaleza: Secretaria da Cultura e Desporto, 1998.

DUSSEL, Enrique. Europa, modernidade e Eurocentrismo. In: A colonialidade do saber: eurocentrimos e ciências sócias. Buenos Aires: Perspectivas latino-americanas, 2005. 
FÉLIX, João Batista de Jesus. Chic show e Zimbabwe e a construção da identidade nos bailes black paulistano. São Paulo, 2000 (Dissertação de mestrado): Faculdade de Filosofia, Letras e Ciências Humanas, USP, São Paulo, 2000.

LIMA, Mariana Semião de. Rap de batom: família, educação e gênero no universo rap. Unicamp, 2005. (Dissertação de Mestrado). Faculdade de Educação Unicamp, Campinas, SP, 2005.

LÜDKE, Menga; ANDRÉ, Marli E.D.A. Pesquisa em educação: abordagens qualitativas. São Paulo: EPU, 1986.

MAGRO, Viviane Melo M. Meninas no graffiti: educação, adolescência, identidade e gênero nas culturas juvenis contemporâneas. Campinas, 2003 (Tese de doutorado): Faculdade de Educação, UNICAMP, Campinas/SP, 2003.

SILVA, José Carlos G. Rap na cidade de São Paulo: música, etnicidade e experiência urbana. Campinas, 1998. (Tese de doutorado): IFCH, UNICAMP, Campinas/SP, 1998. 